\title{
Economic History Association
}

Taxes and Agrarian Life in Early Modern France: Land Sales, 1550-1730

Author(s): Philip T. Hoffman

Source: The Journal of Economic History, Vol. 46, No. 1 (Mar., 1986), pp. 37-55

Published by: Cambridge University Press on behalf of the Economic History Association

Stable URL: http://www.jstor.org/stable/2121266

Accessed: 17-03-2016 23:46 UTC

\section{REFERENCES}

Linked references are available on JSTOR for this article:

http://www.jstor.org/stable/2121266?seq=1\&cid=pdf-reference\#references_tab_contents

You may need to $\log$ in to JSTOR to access the linked references.

Your use of the JSTOR archive indicates your acceptance of the Terms \& Conditions of Use, available at http://www.jstor.org/page/ info/about/policies/terms.jsp

JSTOR is a not-for-profit service that helps scholars, researchers, and students discover, use, and build upon a wide range of content in a trusted digital archive. We use information technology and tools to increase productivity and facilitate new forms of scholarship. For more information about JSTOR, please contact support@jstor.org. 


\title{
Taxes and Agrarian Life in Early Modern France: Land Sales, 1550-1730
}

\author{
PhILIP T. HofFMAN
}

\begin{abstract}
Between 1550 and 1730, privileged investors in France-nobles, officers, and wealthy merchants-bought up enormous quantities of land from peasants. The transfer of property has attracted considerable attention from historians, but it has never been satisfactorily explained. The paper invokes the tax exemptions the privileged enjoyed to account for the transfer-an explanation that fits both the chronology of the land sales and the identity of the purchasers. The paper then examines how the tax system throttled growth in the agricultural sector.
\end{abstract}

SOCIAL historians of early modern Europe have by and large ignored Staxation. The neglect is perhaps understandable: social history itself arose as a revolt against traditional political history and all that it entailed, including the operations of the fisc. Yet taxation had a large effect on the common people of early modern Europe, an effect far beyond the seizure of coins from their pockets. Those who were supposed to pay taxes strove to escape the fiscal burden, and people caught in the tax collector's grip sought to manipulate the system. When the Muscovite government imposed a household tax in the seventeenth century, for example, families "doubled up to cut their taxes." The result, one historian claims, was the birth of the extended family in Russia. In sixteenth-century France the taxes levied on Parisian meat and livestock drove butchers, consumers, and livestock dealers to trade in towns outside the capital; and Parisian students worked their way through school by placing their personal exemptions from wine taxes at the service of vineyard owners. ${ }^{1}$ Moreover, the structure of taxation can inform broader issues, such as the shape of social stratification, the persistence of communal property rights, and the causes of economic stagnation. By ignoring taxes, then, the social historian overlooks their direct impact and blinds himself to a major influence on society.

One such influence was the great wave of land sales in France. From approximately 1550 to the early 1700 s nearly every region of the kingdom saw merchants, lawyers, royal officials, and noblemen buy up

Journal of Economic History, Vol. XLVI, No. 1 (March 1986). (C) The Economic History Association. All rights reserved. ISSN 0022-0507.

The author is Associate Professor of History and Social Science at the California Institute of Technology, Pasadena, California 91125. He wishes to thank the following individuals for their suggestions and criticisms of earlier drafts of this paper: Philip Benedict, John Benton, James Collins, Lance Davis, Jonathan Dewald, Jack Goldstone, Donald McCloskey, Kathryn Norberg, James C. Riley, Hilton Root, and Ken Sokoloff.

${ }^{1}$ Richard Hellie, Slavery in Russia, 1450-1725 (Chicago, 1982), pp. 413, 419, 705-6; Martin Wolfe, The Fiscal System of Renaissance France (New Haven, 1972), pp. 318, 323. 
land from debt-ridden peasants, either by purchasing the peasants' fields outright or by foreclosing on mortgages. The records of the great exchange fill page after page of notarial registers, and it was obvious enough to have attracted the attention of contemporaries. In Lyon, for instance, the local historian and minor humanist Guillaume Paradin described in 1573 how the city's wealthy merchants and bankers had been buying land from peasants at bargain prices:

The poor laboureurs, lacking enough to eat, were constrained to put their lands up for sale at rock bottom prices to rich people, who thereby acquired good lands and vineyards for a morsel of bread. In this way, many have built beautiful farms and villas, constructing their country houses upon the misery of paupers. ${ }^{2}$

Evidence from Saint-Genis-Laval, a small market town south of Lyon, exemplifies what Paradin observed in the Lyonnais and what his contemporaries observed in other regions of France. In Saint-Genis, peasant land passed into the hands of bourgeois from Lyon; the purchasers from Lyon were the sort of merchants and bankers whom Paradin had in mind. ${ }^{3}$ In 1388 , citizens of Lyon owned a mere 4.1 percent of the land in Saint-Genis, and in 1493 they owned not much more-only 12.4 percent. But their ownership increased to 33.0 percent by the late seventeenth century-a transfer of close to 300 hectares (Table 1).

Although they began a bit earlier than in other places, the land sales and the rush to invest in land in Saint-Genis-Laval were in fact symptomatic of what was happening throughout France. In Dauphiné, for instance, ecclesiastics and nobles (including noble officeholders) were buying up peasant land. South of Paris, in the community of Avrainville, it was Parisians-chiefly royal officials. They increased their share of the land from 19 percent in 1546 to 57 percent in 16641674. Peasants in Avrainville went from owning 47 percent of the land in 1546 to 20 percent in 1664-1674 and under 17 percent in 1688 . In the nearby villages of Antony and Monteclin the story was similar: peasant ownership dropped from 26 and 27 percent in the middle of the sixteenth century to 15 percent or less in the late seventeenth century. The same story can be told of numerous other regions, from Picardy in the north to Languedoc in the south, and from Burgundy in the east to the Gâtine Poitevine in the west. Nearly everywhere, the French peasant, who had

\footnotetext{
${ }^{2}$ Quoted Richard Gascon, Grand commerce et vie urbaine au XVIe siècle: Lyon et ses marchands, 2 vols. (Paris, 1971), vol. 2, p. 841. For additional instances of contemporary complaint, see Archives municipales de Bourg-en-Bresse (Ain), AA 11; and Llewain Scott Van Doren, "War Taxation, Institutional Change, and Social Conflict in Provincial France-The Royal Taille in Dauphiné, 1494-1559," Proceedings of the American Philosophical Society, 121 (1977), p. 84.

${ }^{3}$ It should be stressed that urbanites were not the only outside buyers in Saint-Genis-Laval. Nor were all the purchasers of peasant land wealthy.
} 
TABLE 1

PERCENT OF LAND IN SAINT-GENIS-LAVAL OWNED BY RESIDENTS OF LYON

\begin{tabular}{lcc}
\hline \hline \multicolumn{1}{c}{ Date } & $\begin{array}{c}\text { Hectares } \\
\text { Owned }\end{array}$ & $\begin{array}{c}\text { Percent of Total } \\
\text { Land in Saint-Genis }\end{array}$ \\
\hline 1388 & 54 & 4.2 \\
1493 & 160.44 & 12.4 \\
$1517-1518$ & 265.11 & 20.5 \\
1687 & $*$ & 33.0 \\
1787 & $*$ & 25.0 \\
\hline
\end{tabular}

* not available

Source and Note: Archives municipales de Lyon, CC 49-50; Marie Thérèse Lorcin, Les campagnes de la région lyonnaise aux XIVe et XVe siècles (Lyon, 1974), pp. 382, 395; Georges Durand, Vin, vigne, et vignerons en lyonnais et beaujolais (Lyon-Paris, 1979), p. 439.

Figures for 1388, 1493, and 1517-1518 were taken from Lyon tax records, which give the area of holdings belonging to residents of Lyon. For 1687 and 1787 , $1^{*}$ had to rely upon terriers, as reported in Durand. The terriers concern only land that was subject to the seignior-a major portion of the community but not all of it. Hence, acreage totals for the terriers are not directly comparable to the earlier area totals. The figures for 1493 and 1517 differ slightly from those given in Lorcin, p. 395 (135 hectares in 1493), and Richard Gascon, Grand commerce et vie urbaine au XVIe siècle, 2 vols. (Paris, 1971), vol. 2, p. 818 (200 hectares in 1517-1518). The differences may result from their having excluded pasture land from their totals.

emerged from the Middle Ages in a relatively strong position, with effective ownership of large amounts of land, found himself falling into debt and selling his property to merchants, royal officers, and nobles. ${ }^{4}$

Marc Bloch called the influx of money into land "the most decisive event in French social history," and Fernand Braudel made it figure prominently in the "defection of the bourgeoisie," whereby early modern merchants abandoned commerce in favor of land, offices, and the trappings of nobility. Emmanuel Le Roy Ladurie described the land transfer as changing "completely the structure of villages, of land holding, and of rural society." The land sales, he and others argued, undermined the independence the French peasantry had achieved at the end of the Middle Ages and helped create a dominant class of noble and upper bourgeois landlords. The landlords consolidated their holdings, and although the consolidation and the concomitant losses by small

\footnotetext{
${ }^{4}$ Bernard Bligny, ed., Histoire du Dauphiné (Toulouse, 1973), pp. 196-98, 206-9, 242-48; Van Doren, "War Taxation," pp. 70-96; Jean Jacquart, La crise rurale en Ile-de-France, 1550-1670 (Paris, 1974), pp. 104-34, 724-52; idem, "Immobilisme et catastrophes," in G. Duby and A. Wallon, eds., Histoire de la France rurale, vol. 2 (Paris, 1975), pp. 251-75; Emmanuel Le Roy Ladurie, "De la crise ultime à la vraie croissance," in Duby and Wallon, Histoire, vol. 2, pp. 42439; idem, "Les masses profondes: la paysannerie," in E. Labrousse and F. Braudel, eds., Histoire économique et sociale de la France, 4 vols. (Paris, 1970-82), vol. 1, pt. 2, pp. 622-32, 786-99; idem, Les paysans de Languedoc, 2 vols. (Paris, 1966), vol. 1, pp. 459, 567-81; Gaston Roupnel, La ville et la campagne au XVIIe siècle: Etude sur les populations des pays dijonnais (Paris, 1922; 2nd ed., 1955); Louis Merle, La métairie et l'évolution agraire de la Gâtine poitevine de la fin du Moyen Age à la Révolution (Paris, 1958); Pierre Deyon, Amiens, capitale provinciale: Etude sur la société urbaine au 17e siècle (Paris, 1967), pp. 323-38. For more on the peasants' effective ownership of land at the end of the Middle Ages, see Marc Bloch, French Rural History: An Essay on its Basic Characteristics, trans. by Janet Sondheimer (Berkeley and Los Angeles, 1970), pp. 106-49; and Robert Brenner, "Agrarian Class Structure and Economic Development in Preindustrial Europe,' Past and Present, 70 (1976), pp. 46, 59, 68-72.
} 
peasants were never carried to the extremes of engrossment in England, they did undeniably alter the face of French agriculture. ${ }^{5}$

Historians agree on the chronology of the land sales and on the identity of the buyers. Give or take a decade or two, most would concur with Le Roy Ladurie that "the great epoque of massive peasant expropriation near Lille, Paris, Dijon, Mâcon, and even Montpellier was . . . the difficult period from 1560 to 1720.' Near Paris and Lyon it started rather earlier. Everywhere the land sales accelerated after the middle of the sixteenth century. They ceased about 1730, except perhaps in the region about Toulouse, where land sales may have continued well into the eighteenth century. ${ }^{6}$ The purchasers were men of privilege: nobles, royal officials (often ennobled or on their way to ennoblement), and wealthy urban lawyers and merchants. ${ }^{7}$

Yet historians have not devised a satisfactory explanation for the land sales. Indeed, most of the reasons offered fail to account for the chronology or the identity of the purchasers. Often, for example, the transfer of property is explained by the poverty of the peasants. Real though it was, the poverty was merely a symptom, not a cause. We need to know precisely what it was that reduced the peasants to poverty, forcing them to sell their land. Why did they not sell before 1550 or after 1730? The mauvaise conjoncture, or unfavorable economic conditions particularly during the "crisis" of the seventeenth century, seems equally vacuous as an explanation. If mauvaise conjoncture meant reduced profits from farming, why did nobles, officers, and merchants continue to buy farms? It is by no means clear in any case that returns from agriculture did fall during the land sales. Agricultural lease rates, which provide a good index of the expected profits to be derived from farming, actually rose in many parts of France in the first half of the early seventeenth century, when enormous quantities of land were

\footnotetext{
${ }^{5}$ Bloch, French Rural History, p. 125; Fernand Braudel, The Mediterranean and the Mediterranean World in the Age of Philip II, trans. by Sian Reynolds, 2 vols. (New York, 1972-1973), vol. 2, pp. 725-34; Le Roy Ladurie, "La paysannerie," p. 795. For an argument that tends to downplay the ultimate significance of the land sales, see Brenner, "Agrarian Class Structure," pp. 73-75.

6 Jacquart, “Immobilisme," pp. 259-75; Le Roy Ladurie, "Vraie croissance,” pp. 424-29, 594; idem, “La paysannerie,"' pp. 622-32, 786-99; Bernard Chevalier, Les bonnes villes de France du XIVe au XVIe siècle (Paris, 1982), pp. 129-49. For the exceptional case of Toulouse, see Le Roy Ladurie, "Vraie croissance," pp. 428-29, 594; and Georges Frêche, Toulouse et la région midipyrénées au siècle des lumières (vers 1670-1789) (np, 1974), pp. 164, 187-209, 457-89. The evidence for continued land sales near Toulouse after 1730 is less than conclusive. Frêche (whose work Le Roy Ladurie refers to) relies almost exclusively upon tax records from the 1680s or 1690s on the one hand, and from the late eighteenth century on the other, and despite his assertions about greater sales after 1730, such tax records say nothing about the detailed chronology of transfers. After all, the land could have changed hands in the years 1680-1730. Furthermore, the figures Frêche does have for loss of peasant land are often strikingly small.

${ }^{7}$ Jacquart, Ile-de-France, p. 733; idem, "Immobilisme," pp. 259-75; Le Roy Ladurie, "La paysannerie,"' pp. 786-99; idem, "Vraie croissance,' pp. 424-29; Chevalier, Les bonnes villes, pp. 129-49; Georges Huppert, Les Bourgeois Gentilshommes (Chicago, 1977), pp. 39-50.
} 
changing hands. ${ }^{8}$ Profits did decline during the crisis years later in the seventeenth century; but we are left without an explanation of the earlier sales.

If on the other hand the mauvaise conjoncture means an abnormal succession of crop failures, then we must somehow demonstrate that the fluctuations of agricultural revenues were greater between 1550 and 1730 than in other years. It would be possible to do this (one could imagine a world in which a higher variation in agricultural revenues favored large investors who could spread risks more effectively, and one could test for a higher variance of revenues using tithe or lease records). But the available quantitative evidence suggests that revenues did not vary more than normally between 1550 and $1730 .^{9}$

A related explanation involves population growth and diminishing returns in agriculture. Le Roy Ladurie and others have argued that increases in population fragmented peasant holdings and reduced many farms to such an extent that they were no longer profitable. ${ }^{10}$ Left with a pitiful existence on a tiny scrap of land, many a peasant was forced to sell. The problem with this argument is that the land sales continued and even accelerated when the national population was stagnant or falling (in 1628-1638, for example, or during the years around 1700) and in regions that suffered persistent population decline (Ile-de-France, Burgundy). In such times and places one would presume that the size of farms would stabilize and that peasants would have no reason to sell. But the sales of land continued. ${ }^{11}$

\footnotetext{
8 Jacquart, “Immobilisme," pp. 250-52.

9 Three tithe series and one series of farm harvest records from various regions of France suggest that gross revenues were no higher in the years 1550-1730 than before or after. For two of the series the coefficients of variation of gross revenues were in fact lower in 1550-1730 than before or after, and in the other two series, although the coefficients of variation were higher, the differences were so slight that they were not significant, even at the 0.25 probability level. (Here gross revenues are defined as tithe collections times price for the tithe series and harvest times price for the harvest series.) Using deviations from a moving average of gross revenues led to similar results. Gross revenues, of course, are not profits, and tithe records always pose problems. The fluctuations of gross revenues, though, ought to have accounted for most of the variation of profits, and the tithe records used are better than most. They were collected annually in kind, and they come from holdings where the area farmed and the tithe rate did not vary significantly. The source for the three series of tithe records, the series of harvest figures, and the associated grain prices are: Le Roy Ladurie, Paysans de Languedoc, vol. 2, pp. 820-22, 844-48 (prices and tithe of wheat at Béziers, 1587-1757); Hugues Neveux, Vie et déclin d'une structure économique: Les grains du Cambrésis (fin du XIVe-début du XVIIe siècle) (Paris, 1980), pp. 396-99, and Joseph Goy and Emmanuel Le Roy Ladurie, eds., Les fluctuations du produit de la dîme: Conjoncture décimale et domaniale de la fin du Moyen Age au XVIIIe siècle (Paris, 1972), pp. 58-66 (prices and tithes of wheat and oats at Cambrai, 1401-1633); Réné Baehrel, Une croissance: La basse provence rurale (fin XVIe siècle1789) (Paris, 1961), p. 554, and Goy and Le Roy Ladurie, Les fluctuations, pp. 245-53 (prices and wheat production figures from the farm of Saint-Louis-de-Casau near Arles, 1621-1786).

${ }^{10}$ Le Roy Ladurie, Paysans de Languedoc, vol. 1, pp. 261-314, 457, 490-91; Jacquart, Ile-deFrance, pp. 247-53.

${ }^{11}$ For periods and regions of population decline, see Jacques Dupâquier, La population française au XVIIe et XVIIIe siècles (Paris, 1979), pp. 11-13, 38-39, 41. For Ile-de-France and Burgundy, see Jacquart, Ile-de-France, pp. 681-82, 699-701, and Roupnel, La ville et la
} 
And this line of reasoning neglects the strategies that peasants adopted in times of population growth. In the countryside around Lyon, for example, peasants sought work in the city when the population was rising. They married later, limiting the size of families and bringing fragmentation to a halt. They shifted to labor-intensive cultivation, such as viticulture. Since the labor-intensive crops seem to have permitted a profit even on small plots of land, it is not clear that population growth and estate fragmentation (even when they occurred) would have forced peasants to sell. ${ }^{12}$ And population growth does not explain why nobles, officers, urban merchants, and other privileged investors predominated among the buyers. The market for land in France was fairly well developed, and peasants could have traded among themselves to avoid excessive fragmentation. Yet it was outsiders who made the overwhelming majority of the purchases.

Similarly, it is not enough to invoke the security and prestige that property ownership conferred to explain the land sales. Owning property undoubtedly fulfilled a variety of nonpecuniary desires, but there is no reason to believe that these became more pronounced after 1550, and less pronounced after 1730. Furthermore the nobles, officers, and privileged bourgeois who bought farm land seemed often more concerned about profits than one might have supposed. Consider, for example, the illustrious Gadagne family from Lyon. Enormously wealthy, they purchased estates in Saint-Genis-Laval and other parts of the Lyonnais. They were singled out by Marc Bloch as a banking and mercantile family which abandoned trade for the greater status (and eventual ennoblement) that seigniories and rural properties conferred. It is true that the Gadagnes bought seigniories and châteaux, and filled their home in Saint-Genis-Laval with expensive furniture and works of art. Yet they made a great effort to round out their agricultural holdings, as if they were concerned about economies of scale in administration, and they invested considerable money in converting grain fields to more profitable vineyards. To say that the Gadagnes and other officers and merchants among the land buyers were merely aping the older military nobility's taste for châteaux is unsatisfactory. Although they did purchase an occasional château, they also bought considerable amounts of peasant land, which carried none of the honor of a seigniory. And they paid too much attention to the business of estate management and

campagne. In the Les paysans de Languedoc, vol. 1, pp. 567-81, Le Roy Ladurie abandons population growth and fragmentation as explanations for purchases of land by urban elites after the mid-seventeenth century. The reason is that by this time the population was declining in Languedoc and fragmentation had ceased. By his logic, though, the sales to elites should have stopped as well.

${ }^{12}$ Georges Durand, Vin, vigne, vignerons en lyonnais et beaujolais (Lyon, 1979), pp. 225-50, $363-86,445-62,507-10$. 
felt too much disdain for the profligacy of military nobles for the charge to ring true. ${ }^{13}$

A far better explanation for the land sales-one that fits both the chronology and the identity of the land buyers-is the French tax system. The connection between the land sales and taxation is simple. While peasant farms bore the brunt of increasingly heavy taxes during much of the period from 1550 to the early 1700s, the nobles and privileged urbanites who spent money on land generally evaded most of the taxes on their rural holdings. The peasant had to pay the taille, which combined features of a land tax and a levy on agricultural income. If he sold his produce in a urban market he might also have to pay excise taxes known as aides. In most parts of France, however, a noble or privileged urbanite did not have to pay the taille, and if he did pay it he usually escaped at a lower rate. Moreover, he could often sell wine and produce from his lands in the city where he lived without paying a full share of the aides. ${ }^{14}$

Near Lyon, for example, if an urban merchant purchased a vineyard from a peasant, the vineyard would in effect be withdrawn from the taille rolls of the peasant's village. The merchant would in theory pay a tax on this property as part of Lyon's own levy on real property, but his assessment would be far less than the portion of the taille the peasant had originally paid. Furthermore the merchant could bring wine from his own vineyard into Lyon without paying the aides. Although the wine he imported was ostensibly for his personal use, he could easily sell it. As the intendant of Lyon complained in 1687, nearly every bourgeois landowner in Lyon took advantage of his exemption from the aides to turn a profit selling wine from his estate. ${ }^{15}$

Elsewhere in France, privileged city dwellers, officeholders, and nobles generally enjoyed similar exemptions, despite efforts made in the

${ }^{13}$ Bloch, French Rural History, p. 124; Joseph Cartellier, Essai historique sur Saint-Genis-Laval avant la Révolution (Lyon, 1927; reprint, Saint-Genis-Laval, 1980); Archives départementales du Rhône, 3 BP 1886 (May 12, 1595), 3869, 3872, fols. 92-98, 163. This assessment of the Gadagnes and their ilk draws upon Huppert, Les Bourgeois Gentilshommes, pp. 24-50, 115-19, 141-44; Chevalier, Les bonnes villes, pp. 129-49; and Jonathan Dewald, The Formation of a Provincial Nobility (Princeton, 1980). One could argue that the tightening of the market for government offices pushed members of the privileged elite to buy land, but the cost of offices did not rise until the end of the sixteenth century, well after land sales began. Nor do office prices explain the end of the land sales in 1730. Similarly, the fluctuations in the value of other investments, such as rentes, do not appear to explain the sales, and it would be difficult to argue that the security of land, albeit considerable, suddenly increased after 1550 and thereby attracted money into the countryside.

${ }^{14}$ In areas of taille réelle, where tax exemptions were tied not to persons but to pieces of land, privileged persons would (at least in theory) have paid the taille on land purchased from commoners. In practice, though, they too often escaped with low tax assessments.

${ }^{15}$ Gascon, Grand commerce, vol. 2, pp. 862-66; Durand, Vin, pp. 481-84; Marcel Marion, Les impôts directs sous l'ancien régime principalement au XVIIIe siècle (Paris, 1910), pp. 187-88. See also Wolfe, Fiscal System, pp. 312, 325-27. 
seventeenth century (particularly by Colbert) to reform the aides and to make the privileged pay the taille on their rural holdings. ${ }^{16}$ The taille in theory would fall upon any tenants who leased land from tax-exempt owners, but the exempt were often able to spare their tenants from taxes. In seventeenth-century Normandy, for instance, a noble or a taxexempt officer could work one of his farms and all of his meadows without paying the taille. Although he was supposed to hire wage labor to do the farming, he could rent the land out and claim that the tenants were domestics. On his other farms his tenants might have to pay the taille, but they almost always did so at a lower rate, usually because the privileged landowner had managed to reduce their assessment. In 1645 in the Norman community of Saint-Ouen-de-Breuil, for example, tenant farmers (many of whom rented from the tax-exempt owners, holding 75 percent of the land) paid only 35 percent of the taille per acre that peasant owners did. The same held true in many other regions of France: tenants of privileged landlords might appear on some taille rolls, but they generally paid at a lower rate if they paid at all. As the military engineer and tax reformer Vauban remarked in 1707, tenants of the privileged were assessed "in name only." Even in many areas of taille réelle, where exemptions from the taille were attached to particular pieces of land and not to individuals, members of the elite managed to reduce their tax burden by manipulating the assessment figures in the communal cadastres. ${ }^{17}$

\footnotetext{
${ }^{16}$ Edmond Esmonin, La taille en Normandie au temps de Colbert (1661-1683) (Paris, 1913), pp. 225-28, 250-56, 271-72; Wolfe, Fiscal System, pp. 310-15; Roland Mousnier, La vénalité des offices sous Henri IV et Louis XIII (Rouen, 1945), pp. 352-56; idem, The Institutions of France under the Absolute Monarchy: 1598-1789, trans. by Arthur Goldhammer and Brian Pearce, 2 vols. (Chicago, 1979-84), vol. 1, pp. 125, 172-73; vol. 2, p. 58; Richard Bonney, Political Change in France under Richelieu and Mazarin (Oxford, 1978), pp. 272-73; Jean-Jules Clamagéran, Histoire de l'impôt en France depuis l'époque romaine jusqu'à 1774, 3 vols. (Paris, 1867-1876; reimpression, Geneva, 1980), vol. 2, pp. 357-59, 619-20; Marion, Les impôts, pp. 9-11.

${ }^{17}$ Esmonin, La taille, pp. 151, 160, 225-28, 250-56, 364-68; Mousnier, Vénalité, pp. 412-15; idem, Institutions, vol. 1, pp. 172-73; vol. 2, pp. 58, 433-35; Bonney, Political Change, p. 448; Pierre Deyon, "A propos des rapports entre la noblesse française et la monarchie absolue pendant la première moitié du XVIIe siècle,"' Revue historique, 231 (1964), pp. 342-43, 354-55; [Sébastien le Prestre de] Vauban, Projet d'une dixme royale: Suivi de deux écrits financiers, ed. E. Coornaert (Paris, 1933), pp. 27-28, 36-37; Bernard Bonnin, "Un aspect de la société rurale: Les milieux dominants en Dauphiné au XVIIe siècle," in J. P. Gutton, ed., Lyon et l'Europe: Hommes et sociétés: Mélanges d'histoire offerts à Richard Gascon, 2 vols. (Lyon, 1980), vol. 1, pp. 60-61; Clamagéran, Histoire de l'impôt, vol. 2, pp. 357-59, 619-20. For comments made in 1717 that resemble Vauban's, see [François Véron de Forbonnais], Recherches et considerations sur les finances de France depuis 1595 jusqu'en 1721, 6 vols. (Liege, 1758), vol. 6, p. 131. The royal government tried repeatedly to tax the tenants of privileged landowners, but the repetition of edicts suggests that the government's efforts were not tremendously successful, at least until the eighteenth century. Even when tenants of privileged landlords were taxed at the full legal rate in the seventeenth century, their tax (the taille d'exploitation) fell far below the tax paid by peasant proprietors (the taille de propriété). Whether it was this difference in the legal taille rates or simply underassessment of the tenants of privileged landlords, the evidence from Saint-Ouen-de-Breuil reveals a huge gap between the taille levied upon rented land and that levied upon peasant-owned
} 
The disproportionate tax burden drove peasant owners out of business. Peasant proprietors fell into debt to pay taxes, which began to rise in the last half of the sixteenth century and did not level off until after 1730. In real terms the per capita tax rose nearly sevenfold between the $1560 \mathrm{~s}$ and the 1730s; the tax burden increased from roughly 0.4 bushels of wheat per person in the $1560 \mathrm{~s}$ to 2.6 bushels in the $1730 \mathrm{~s}$, or from 8 days labor for a Parisian construction worker and his family in the $1560 \mathrm{~s}$ to over 40 days labor by the 1720 s (Table 2 , columns 4 and 5). ${ }^{18}$

Crushed by the higher taxes, peasant proprietors sold out to privileged investors. They in turn were willing to purchase the land (and willing to pay more for it than any peasant) because it allowed them to exploit their tax exemptions. As Vauban remarked in 1707, the exemptions raised the value of the privileged investors' property relative to land held by tax-paying peasants-which presumably dropped in price every time the taille was raised.

land. A regression of taille assessments from the year 1645 (TAILLE, in livres tournois) on the acres of land each peasant owned $(O W N)$ and the acres he rented (RENT) yielded the following:

$$
\begin{aligned}
& T A I L L E=11.80+0.57 O W N+0.20 R E N T \\
& R^{2}=0.91 \quad \mathrm{n}=78 \quad t=17.44 \quad t=19.65
\end{aligned}
$$

The hypothesis that peasant property in Saint-Ouen-de-Breuil was assessed at less than twice the rate of rental property can be firmly rejected ( $t=4.01$ with 75 degrees of freedom). It is therefore clear that renters in Saint-Ouen-de-Breuil did not pick up the tax for privileged landlords. The source for the individual taille assessments, acres rented, and acres owned in Saint-Ouen-de-Breuil comes from an unusually complete 1645 taille roll in Archives dépt. de la Seine-Maritime, C 2108 (1645). I thank James Collins for furnishing me a copy and for the information that 75 percent of the land was in the hands of the exempt.

${ }^{18}$ Rough estimates suggest that taxes also increased as a fraction of agricultural output: Michel Morineau, "La conjoncture ou les cernes de la croissance," in Labrousse and Braudel, Histoire économique, vol. 1, pt. 2, p. 980. Peter Mathias and Patrick O'Brien, in "Taxation in Britain and France, 1715-1810: A Comparison of the Social and Economic Incidence of Taxes Collected for the Central Governments," Journal of European Economic History, 5 (1976), pp. 601-50, arrive at similar figures for the wheat equivalent of per capita taxes in the eighteenth century. The labor equivalent of the tax burden was derived using figures in Micheline Baulant, "Les salaires des ouvriers du bâtiment à Paris de 1400 à 1726," Annales, 26 (1971), pp. 463-83. The calculation assumes that the Parisian worker is the sole support for a family of four. The $\mathbf{4 0}$ days he spends working for the fisc amounts to approximately 16 percent of the labor year. See also Charles Tilly, As Sociology Meets History (New York, 1981), p. 203. It should be pointed out that the central government's tax receipts, which form the basis of Table 2, actually understate the weight of royal taxation in the provinces, for they ignore collection costs and omit tax revenues that were spent directly in the provinces without being remitted to Paris. On this and related matters, see Van Doren, "War Taxation," p. 70; William Beik, "Etat et société en France au XVIIe siècle: La taille en Languedoc et la question de la redistribution sociale," Annales, 39 (1984), pp. 1270-98; and James B. Collins, "Sur l'histoire fiscale du XVIIe siècle: Les impôts en Champagne entre 1595 et 1635,' Annales, 34 (1979), pp. 325-47. Still, despite the problems with the central government's tax figures, the few long-term series of local tax receipts that we have do sketch the same chronology for the rise in real taxes: see, for example, Le Roy Ladurie, Paysans de Languedoc, vol. 2, p. 1026, and Beik, "Etat,"' pp. 1281-83. One might wonder whether Table 2, which includes all tax levies, might misrepresent the size of the taille and the aides, the taxes of greatest interest to us. The answer is no. Although the per capita taille apparently peaked in the 1670s (separate taille and aides figures are not available for all years), aides receipts were increasing, and the sum of the two levies probably followed the total tax receipts curve fairly closely. 
TABLE 2

PER CAPITA ROYAL TAX RECEIPTS

\begin{tabular}{|c|c|c|c|c|}
\hline Decade & $\begin{array}{c}\text { Average } \\
\text { Annual } \\
\text { Taxes }{ }^{1} \\
\text { (nominal) }\end{array}$ & $\begin{array}{c}\text { Average } \\
\text { Annual } \\
\text { Per } \\
\text { Capita } \\
\text { Taxes }^{2} \\
\text { (nominal) }\end{array}$ & $\begin{array}{c}\text { Grain } \\
\text { Equivalent }^{3}\end{array}$ & $\begin{array}{c}\text { Index of Real } \\
\text { Per Capita } \\
\text { Taxes }^{4}\end{array}$ \\
\hline $1560 / 69$ & 10.22 & 0.60 & 0.38 & 100 \\
\hline $1570 / 79$ & 23.12 & 1.36 & 0.67 & 174 \\
\hline $1580 / 89$ & 30.39 & 1.79 & 0.78 & 204 \\
\hline $1590 / 99$ & 24.80 & 1.46 & 0.44 & 114 \\
\hline $1600 / 09$ & 24.90 & 1.44 & 0.65 & 169 \\
\hline $1610 / 19$ & 30.37 & 1.71 & 0.73 & 191 \\
\hline $1620 / 29$ & 43.47 & 2.39 & 0.79 & 207 \\
\hline $1630 / 39$ & 92.16 & 4.91 & 1.59 & 414 \\
\hline $1640 / 49$ & 114.64 & 5.95 & 1.64 & 428 \\
\hline $1650 / 59$ & 126.79 & 6.42 & 1.49 & 388 \\
\hline $1660 / 69$ & 91.72 & 4.49 & 1.23 & 321 \\
\hline $1670 / 79$ & 108.95 & 5.20 & 1.83 & 477 \\
\hline $1680 / 89$ & 119.28 & 5.59 & 1.85 & 482 \\
\hline $1690 / 99$ & 145.83 & 6.78 & 1.66 & 434 \\
\hline $1700 / 09$ & 117.99 & 5.74 & 1.52 & 398 \\
\hline $1710 / 19$ & 130.82 & 6.23 & 1.39 & 362 \\
\hline $1720 / 29$ & 198.00 & 9.21 & 1.95 & 509 \\
\hline $1730 / 39$ & 211.00 & 9.34 & 2.56 & 669 \\
\hline $1740 / 49$ & 223.00 & 9.61 & 2.19 & 572 \\
\hline $1750 / 59$ & 230.00 & 9.80 & 2.25 & 587 \\
\hline $1760 / 69$ & 319.00 & 12.97 & 2.69 & 703 \\
\hline $1770 / 79$ & 362.00 & 14.03 & 2.35 & 612 \\
\hline
\end{tabular}

${ }^{1}$ Millions of livres tournois, uncorrected for inflation and devaluation.

${ }^{2}$ Livres tournois, uncorrected for inflation and devaluation.

${ }^{3}$ Average annual grain equivalent of per capita taxes (in bushels of wheat).

${ }^{4}$ Constant value livres, with $1560 / 69=100$. This column represents the numbers of column 4 divided by 0.38 , the grain equivalent for $1560 / 69$, and then multiplied by 100 .

Source: Unless otherwise noted, figures for total annual tax receipts were taken from Alain Guéry, "Les finances de la monarchie française sous l'ancien régime," Annales, 33 (1978), pp. 216-39, whose chief source is J. R. Mallet, Comptes rendus de l'administration des finances du royaume de France (London and Paris, 1789). As Richard Bonney points out in The King's Debts: Finance and Politics in France, 1589-1661 (Oxford, 1981), pp. 304-6, Guéry fails to include revenue from a source known as the parties casuelles in his tax figures for the years 1611-1656. I have corrected Guéry's totals for these years by adding the parties casuelles figures given in Mallet. For 1661 and 1672-1681, Guéry gives no tax receipts; I therefore relied upon Mallet for these years. Tax figures for 1716-1717 come from [François Véron de Forbonnais], Recherches et considerations sur les finances de France depuis 1595 jusqu'en 1721, 6 vols. (Liege, 1758), and those for the years after 1717 are taken from Peter Mathias and Patrick O'Brien, "Taxation in Britain and France, 17151810: A Comparison of the Social and Economic Incidence of Taxes Collected for the Central Governments,' Journal of European Economic History, 5 (1976), pp. 601-50. On the basis of figures in Emmanuel Le Roy Ladurie, "Les masses profondes: La paysannerie," in F. Braudel and E. Labrousse, eds., Histoire économique et sociale de la France (Paris, 1977), vol. 1, pt. 2, pp. 485, 560-61, 730, and Jacques Dupâquier, La population française au XVIIe et XVIIIe siècles (Paris, 1979), p. 11, I assumed that France had a population of 17 million in 1560 and 17 million in 1600 within contemporary frontiers. Population figures after 1600 were taken from Dupâquier, pp. 11$12,34-37,81$; to correct them for the size of contemporary frontiers, I used figures on the area of France given in Roland Mousnier, The Institutions of France Under the Absolute Monarchy, 15891789 , trans. Arthur Goldhammer and Brian Pearce, 2 vols. (Chicago, 1979-1984), vol. 1, pp. 68286. The grain equivalent of per capita taxes and the index of real per capita taxes were calculated 
The exemptions were large enough to affect land prices appreciably. As early as the fifteenth century the annual exemptions from the aides enjoyed by a typical magistrate of the Parlement of Paris might be worth a quarter of his yearly salary, and they would have been worth more under the higher taxes of the sixteenth and seventeenth centuries. ${ }^{19}$ The tax exemptions, further, could account for the land sales even if a privileged buyer was concerned only about his social status: a tax exemption would make a prestigious estate less costly to operate.

A bit of economics will explain why the land sales finally came to a halt. In the long run one would expect a peasant to pay for land an amount equal to the net revenue it brought in. For a given piece of land he would pay the discounted value of the net pre-tax revenue he received from the land, minus the taxes he had to pay. The same would hold for a privileged landlord, but he would face different costs and much smaller taxes, if indeed he paid taxes at all. As an absentee, the privileged landlord bore the additional cost of overseeing the land and its tenants-disposing of crops from afar, supervising laborers, and ensuring that tenants paid their rent and did not abuse buildings, trees, or animals. The costs of supervision, which an owner-occupier such as a peasant did not have to pay, were of great concern to contemporaries, and they could loom large enough to make a distant plot of land worthless for an absentee owner. ${ }^{20}$

As long as the supervisory costs were low a privileged investor would pay more for a piece of land than a peasant because of his lower taxes,

${ }^{19}$ Vauban, Projet, pp. 27-28; Françoise Autrand, Naissance d'un grand corps de l'état: Les gens du Parlement de Paris, 1345-1454 (Paris, 1981), pp. 210-43, 351. For additional contemporary perceptions of the effect exemptions had on land values, see de Forbonnais, Recherches, vol. 6, p. 131. In Saint-Genis-Laval in the early eighteenth century, taille exemptions held by three officials from Lyon (none of them owners of huge estates) cost the community 700 livres annually, a considerable sum: Archives dépt. du Rhône, 1 C 51, "Etat du nombre des privilégiés." An arrêt from 1734 in the same bundle of documents reveals that an attempt in 1705 to limit tax exemptions to contiguous pieces of property caused privileged landlords to consolidate their holdings-further evidence of the effect tax exemptions had.

${ }^{20}$ On costs of supervision, see Olivier de Serres, Le théâtre de l'agriculture (Paris, 1600), pp. 45-54; Dewald, Formation, pp. 183-201. It would be relatively easy to change this simple model to include risk aversion, subsistence farming by peasants, or the nonpecuniary benefits that landownership conferred.

\section{Table 2, Sources (continued):}

using as a deflator a nine-year moving average of wheat prices in Paris, derived from Micheline Baulant, “Les prix des grains à Paris de 1431 à 1788," Annales, 23 (1968), pp. 520-40.

Note: Extrapolation was used to fill in population figures for each of the years after 1560 . For any given decade, the figures in columns 2 through 5 represent averages for the years in the decade in question. Tax figures are available in the sixteenth century only for the years 1567, 1574, 1576$1577,1581-1582,1586,1588,1596-1597$, and they are missing for 1657-1660 in the seventeenth century. In the eighteenth century, figures are given for the following years only: 1700-1703, 1705$1715,1725,1730,1734,1740,1742,1751,1756,1763,1768$, and 1775 (actually an average for 17731776). For the difficulties of finding figures for French taxes in the eighteenth century, see Mathias and O'Brien, "Taxation," pp. 601-50. For an important word of caution about all these figures, see William Beik, "Etat et socíeté en France au XVIIe siècle: La taille en Languedoc et la question de la redistribution sociale," Annales, 39 (1984), pp. 1270-98. 
and as a result the privileged would buy up all land for which supervision cost little. His purchases would stop once the costs of administering distant estates outweighed the advantages of a tax exemption. Since the supervisory costs would increase with distance, privileged landlords would tend to buy land lying within a certain number of miles of their homes; at greater distances they would tend to have no holdings. If the privileged landlords all lived within a city-a reasonable assumption-then their holdings would therefore tend to cluster, all other things being equal, near the city's walls. This is precisely what happened in the vicinity of Lyon and Paris. ${ }^{21}$

Given the structure of exemptions, the taxes peasants faced were bound to increase more than the taxes levied on the privileged, and each tax increase would therefore encourage the privileged to buy more land, until the costs of administering distant estates once again balanced the tax exemptions. The process would come to a halt only when taxes ceased to grow, or when the government limited exemptions. In real terms, per capita taxes dropped temporarily after 1690, and after reaching a peak again in the 1730 s they leveled off until late in the eighteenth century (Table 2 , column 5). ${ }^{22}$ A campaign against tax exemptions enjoyed by privileged landlords and their tenants also contributed to halting the land sales. Colbert had taken steps against the exemptions but without effect. It was not until the end of the seventeenth century and the early decades of the 1700 s that intendants, now able to raise flagrantly low tax assessments in individual villages, began to crack down in earnest on privileged landlords and their tenants. In Saint-Genis-Laval and surrounding communities in the Lyonnais, for example, the intendant began as early as 1687 to take steps against privileged landowners (in this region, chiefly bourgeois from Lyon), and in 1734 the royal government sharply restricted their rights to claim tax exemptions for rural holdings. Previous legislation had attempted the same thing, but this time the law was enforced. By the 1730s numerous bourgeois in the Lyonnais found their property listed on the taille rolls, and their tenants paid the taille on the same footing with peasant owners. Intendants in other parts of France launched a similar campaign against nobles, officers, and other privileged persons. The effectiveness of this campaign prevented the land sales from resuming when taxes finally rose again late in the eighteenth century. ${ }^{23}$

\footnotetext{
${ }^{21}$ Gascon, Grand commerce, vol. 2, pp. 817, 848-51. In Jacquart's study, the one community where the peasants retained their land was far from Paris and from the other cities where privileged landlords usually resided (Jacquart, Ile-de-France, p. 724).

${ }^{22}$ Mathias and O'Brien, "Taxation," pp. 608-11, reach similar conclusions about the trend of per capita real taxes in the eighteenth century. The leveling off of taxes also helped quell endemic tax revolts.

${ }^{23}$ For tax reform and the campaign against exemptions, see Marion, Les impôts, pp. 6-11, 127, 129, 131 , 187-88, 190-94; Deyon, "Rapports,"' pp. 354-55; Bonney, Political Change, pp. 424-25, 433, 437-38; Mousnier, Institutions, vol. 1, p. 172, vol. 2, pp. 433-35; Clamagéran, Histoire de
} 
Taxes (and tax inequities) increased considerably in the middle of the sixteenth century, at just the time that the money began to flow into land. There was not much relief until the early eighteenth century. Furthermore, the transfer of peasant land peaked during the periods of the greatest tax increases-during the Thirty Years War, for examplewhen the gap widened between what the privileged would pay for land and what peasants would accept. One can explain the apparently premature transfers of land near Lyon and Paris: the tax exemption for rural property owned by the bourgeois of Lyon dated back to 1462, and the magistrates of the Parlement of Paris won their exemption from the aides as early as the fifteenth century. ${ }^{24}$

This is not to say that the inequities of the tax system were the only cause. There is for instance an anomaly in the countryside about Toulouse. Here population increase might have played a role, and elsewhere agricultural crises might have been a contributing factor, alongside the tax increases. There may also be some merit to Bloch's assertion that the peasants sold their land because they lacked cash (unlike the nobles, officers, and other privileged buyers). According to Bloch, rising royal taxes forced peasants to come up with hard currency to pay their taxes. Without any reasonable source of credit the peasants simply had to sell their fields. Bloch's argument assumes, of course, that credit markets were imperfect. Most historians would probably agree, although the assumption certainly deserves further investigation. The risks of agricultural lending were high. It is not enough merely to cite evidence of high interest rates in order to conclude that moneylenders were monopolistic usurers or that credit markets had failed. In Saint-Genis-Laval, for example, where many peasants themselves engaged in money lending, the market for loans was fairly competitive,

l'impôt, vol. 2, pp. 357-59, 619-20, vol. 3, p. 41. Marion contains examples from regions other than the Lyonnais where intendants used taxes d'office and other techniques to attack exemptions in the late seventeenth and early eighteenth centuries. In the Lyonnais, a royal arrêt of 1734 concerning the bourgeois of Lyon restricted their taille exemption to one contiguous piece of property of less than 10 hectares, including woodlands and vineyards. This represented a far more serious limit than did seventeenth-century legislation, which did not cover woods and vines and which granted bourgeois of Lyon exemptions covering a far more liberal 45-60 hectares. Nobles and officers enjoyed even more liberal privileges under seventeenth-century law. Archives dépt. de Rhône, $1 \mathrm{C}$ 51 , contains the arrêt of 1734 plus evidence that it was being enforced and that tenants were being taxed equitably. See also Archives dépt. du Rhône, 3 C 96 (1756, 1759), where bourgeois from Lyon claim only the limited protection of the 1734 arrêt. The shift to indirect taxes late in the seventeenth century and the new taxes imposed in the eighteenth century (especially the vingtième) further restricted exemptions, for, whatever their failings, these indirect taxes and the vingtième were less riddled with loopholes than the taille. Taille rolls from Normandy also suggest that by the eighteenth century, tenants of privileged landlords no longer evaded the taille; see, for example, Archives dépt. de la Seine Maritime, C 2108, Nossonville (1727).

${ }^{24}$ For an example of land purchases when taxes were high, see Deyon, Amiens, pp. 332-38. For Lyon and Paris, see Gascon, Grand commerce, vol. 2, pp. 862-67, and Autrand, Naissance, pp. 210-43. 
and it is therefore difficult to trace the loss of peasant land in SaintGenis back to failures of credit markets. ${ }^{25}$

In the few areas of France where the privileged could not readily exploit tax exemptions, the transfer of peasant land into their hands should be insignificant. Lower Provence is one such area. Cheating on taille assessments was uncommon there, and the peasants did not usually sell their land. ${ }^{26}$ There is more dramatic evidence of this sort in Vénissieux, a village south of Lyon, across the Rhône River from SaintGenis-Laval. Although Vénissieux was no further from Lyon than Saint-Genis, the privileged investors from Lyon behaved differently in Vénissieux than in Saint-Genis, where they had been acquiring property throughout the sixteenth and seventeenth centuries (see Table 1). The only way to explain the contrast between the two communities is to invoke differences between the local tax systems. Vénissieux lay just over the border of Dauphiné, and in Dauphiné tax exemptions worked differently, at least for absentee landlords from Lyon. Although tax exemptions for the privileged existed in Dauphiné (exemptions there provoked a long legal battle in the sixteenth and seventeenth centuries), the citizens of Lyon did not enjoy firm immunities for the property they owned in the province. In 1545 , it is true, the monarchy did exempt residents of Lyon from the taille for land they owned in Dauphiné, and like other local urbanites they undoubtedly possessed similar exemptions earlier in the century as well. But as early as 1543 the residents of villages such as Vénissieux placed landlords from Lyon on the taille rolls for their local holdings. Though the royal exemption undoubtedly kept the villagers from collecting the taxes they had assessed in 15431544 , the same was not true later. By the $1550 \mathrm{~s}$, in fact, villages in Dauphiné had begun to tax the holdings of non-noble urban landlords. By the 1640s, after a long court battle, they had moved toward a more equitable tax system, which allowed even nobles to be taxed. ${ }^{27}$

\footnotetext{
${ }^{25}$ Le Roy Ladurie "Vraie croissance," pp. 428-29, 594; Frêche, Toulouse, pp. 140, 164, 187-209, 457-89, 504; Bloch, French Rural History, p. 140. The evidence from Saint-Genis-Laval comes from research I am doing in local notarial records from Archives dépt. du Rhône, 3 E. Even with a number of lenders in Saint-Genis-Laval, the problem of default might have introduced imperfections into the credit market. Although this matter of peasant debt occupies a large place in the social history of the period, it is largely irrelevant to my explanation for the land sales. Whether a peasant owner was driven into debt by taxes or not, the higher price offered by the privileged would make him sell his land to them instead of to other peasants.

${ }^{26}$ Baehrel, Une croissance, pp. 403-6, 476-77. In areas where the privileged could exploit tax exemptions, the price of land should have remained relatively insensitive to increases in taxes, for when taxes rose, the amount the privileged would pay for land would have declined slightly, if at all. In areas like lower Provence, by contrast, land prices should have dropped considerably whenever taxes increased. The problem with testing this, however, is the nearly insurmountable one of getting a long time series of land prices or rents that controls for land quality and a matching series of local tax figures.

${ }^{27}$ Gascon, Grand commerce, vol. 2, pp. 862-63; Van Doren, “War Taxation,” pp. 82-90; Bligny, Histoire du Dauphiné, pp. 204-9, 227-49, 257-73.
} 
The residents of Lyon thus lost their exemption for property in Dauphiné in general and in Vénissieux in particular. This was probably the case by the end of the sixteenth century, and it was certainly so by the 1640s. The loss of this exemption would be expected to affect residents of Lyon who held property in Vénissieux. They should have sold their plots once they had to start paying taxes, and the proportion of land held by the Lyonnais should have declined. Other investorsnobles, for example-might have continued to invest in Vénissieux, but the Lyonnais should have given up the ghost.

This is precisely what happened, if one can believe the taille figures. According to the taille roles, the absentee landlords from Lyon owned less property in Vénissieux in 1661 than in 1543-1544 (Table 3). One hesitates, of course, to translate the taille directly into landholdings, for elites could manipulate the assessments. The Lyonnais, however, lacked the political and legal tools to engage in such trickery in Dauphiné (if anything, they were likely to be overassessed), and in any event they were probably less able to influence the taille rolls as time went on. In all likelihood, then, the taille rolls from Vénissieux probably understate the decline in property ownership by the Lyonnais. By contrast, in Saint-Genis-Laval, just across the river, the Lyonnais were buying up more and more land (Table 1). The explanation is clearly the tax exemption.

The tax exemptions also shed light on the growing stratification in peasant communities. The sort who rose in the peasant communities were in the first place those who had the skills to farm or to manage estates for the growing number of absentee landlords. They had the assets, reputation, and experience needed to be an absentee landlord's agent, or fermier; the relationship they enjoyed with landlords might bring them lower tax assessments as well. If they were literate they might also purchase minor tax-exempt offices. Most important, they usually had a stranglehold over village and seigniorial offices, which allowed them to manipulate tax assessments and other village affairs in their favor. The result was that wealthy peasants-the coqs $d u$ village, marchands-laboureurs, or fermiers-receveurs-profited. In particular they usually paid lower taxes. They acquired farm land and rose in the village, while most other peasants lost their property and fell. ${ }^{28}$

${ }^{28}$ For the stratification of the rural community, see Le Roy Ladurie, Paysans de Languedoc, vol. 1, pp. 261-314; Jacquart, Ile-de-France, pp. 248-53, 450-540; idem, "Immobilisme”, p. 261; Bloch, French Rural History, pp. 136-37. For the village elite's ability to gain tax exemptions and manipulate tax assessments (either on their own or via the patronage of absentee landlords), see Esmonin, La taille, pp. 151, 160, 225-28, 364-68; and Bonney, Political Change, pp. 181, 446-49. For the small offices a member of the village elite might buy, see Mousnier, Vénalité, pp. 404-15. In addition to earning a return on their skills and assets, the members of the village elite may have colluded with the tax-exempt and thus have shared some of the advantages of the tax break. For the rest of the peasantry, though, the possibility of splitting the benefits of tax evasion does not seem to have been in the cards politically. 
TABLE 3

PERCENT OF THE TAILLE ASSESSED TO RESIDENTS OF LYON IN VÉNISSIEUX

\begin{tabular}{cc}
\hline Date & Percent \\
\hline $1543-1544$ & 37 \\
$1598-1599$ & $38^{*}$ \\
1661 & 10 \\
\hline
\end{tabular}

* Figure includes percent of taille assessed to residents of Lyon and all other taille-paying absentee landlords. The percent of the taille paid by landlords from Lyon is therefore less (and perhaps considerably less) than the 38 percent figure.

Note: For 1598-1599, three taille rolls were averaged together. For 1661, the area of Feysin was excluded.

Source: Archives dépt. de l'Isère, B 3066, fols. 158-99 (1543-1544); AD Rhône, E supplément, fonds des communes, Vénissieux taille rolls $(1598-1599,1661)$.

The royal government was concerned about the sale of peasant land, for the sale eroded the government's tax base. In the seventeenth century the monarchy therefore made an effort to limit tax exemptions, and although the king often spoke of these tax reforms as a means of protecting the poor, the desire to increase tax revenues always lay somewhere near the surface. One example of the monarchy's efforts was its investigation of titles of nobility-an investigation undertaken in part to reduce false claims to fiscal exemptions. The crown also struggled against exemptions and low tax assessments for officers, city dwellers, and village elites. ${ }^{29}$

The crown took direct measures to stem the sale of some peasant land as well. Actually limiting sales by individual peasants was beyond the government's means, although it had been attempted in similar situations by governments of small German principalities. ${ }^{30}$ Indeed, no one in France appears to have contemplated this alternative, which in any case would have been prohibitively expensive to enforce. But the government did place restrictions on the sale of the property rights belonging to entire villages. Typically, villages in France owned commons such as meadows, forests, or waste lands, where peasants enjoyed communal rights to graze animals or collect wood; and villages might possess the vaine pature, the collective right to pasture in unenclosed fields. Parish vestries in villages also had plots of cultivated land, which might be leased out to help defray village expenses. Much of this communal property, though, had to be sold to pay mounting expenses during the Wars of Religion, the Fronde, and other crises of the late sixteenth and seventeenth centuries. Throughout France the villages had to rebuild parish churches devastated by warring religious factions, lodge marauding troops or bribe them to stay away, and pay for lawyers and court costs in cases involving higher taxes. Villages had no alternatives to selling their land and their use rights, such as the vaine

29 Esmonin, La taille, pp. 57-58, 201-2, 271-72; Bonney, Political Change, pp. 437-38, 446-49.

${ }^{30}$ Friedrich Lütge, Geschichte der deutschen Agrarverfassung (Stuttgart, 1963), pp. 136-37. 


\section{pâture. The communal property ended up in the hands of privileged} buyers. ${ }^{31}$

The peasants who leased vestry land probably paid some taxes, and the commons and use rights figured into the assessments for the taille. Indirectly, then, the peasants paid taxes on communal land. But once this property was in the possession of the exempt, the monarchy lost the tax revenue.

Under Louis XIV the monarchy forced some of the purchasers of communal property to return what they had bought, and it squeezed a little from other buyers. It also placed the villages in a position of financial tutelage. Henceforth, the royal intendants supervised village finances, limited communal expenditures and repairs, and prohibited the sale or mortgage of communal property. The government's motive was simply to prevent further hemorrhaging of taxable assets. One consequence of the policy was to make the monarchy one of the main guarantors of communal property rights and of communal agriculture in general. Its thirst for taxes had pushed it to support both communal rights and traditional agricultural practices. ${ }^{32}$ Communal agriculture in France was not swept away by a wave of enclosures, as it was in England. ${ }^{33}$

${ }^{31}$ See, for example, Jacquart, Ile-de-France, pp. 220-23; Roupnel, La ville et campagne; and Mousnier, Institutions, vol. 1, pp. 555-61. For sales of rights to vaine pâture, see Marc Bloch, "La lutte pour l'individualisme agraire dans la France du XVIIIe siècle,', Annales, 2 (1930), p. 339; and Archives nationales, G7 101 (1678). In the late eighteenth century, some 10 percent of the agricultural land belonged to the villages: Guy Ikni, "Sur les biens communaux pendant la Révolution française," Annales historiques de la Révolution française, 54 (1982), pp. 73-74. In addition to the communal land itself, village use rights such as the vaine pature could extend (in regions such as the northeast) over nearly all a community's arable land.

${ }^{32}$ See Mousnier, Institutions, vol. 1, pp. 559-61, and Hilton Root, "Crown and Peasantry in Burgundy, 1661-1798"' (Ph.D. diss., University of Michigan, 1983), the best local study of the monarchy's takeover of village finances and its effect upon agriculture. A revised version of Root's dissertation is forthcoming from the University of California Press.

${ }^{33}$ For the obstacles to enclosures, see Root, "Crown and Peasantry," and Bloch, "La lutte pour l'individualisme agraire,'” pp. 329-83, 511-56. The peculiarities of the tax system were not the only reason communal agriculture was slow to disappear in France, and in the last half of the eighteenth century many government officials did push for the passage of enclosure edicts and other measures against communal farming. But enforcement of these measures often ended up in the hands of staunch defenders of communal rights like the intendant of Rouen, De Crosne. In 1780, for example, De Crosne preserved communal rights to a pasture shared by inhabitants of the two communities of Petit-Quevilly and Grand-Quevilly even though the residents of Petit-Quevilly acknowledged that sharing rights between the two villages cut productivity and frustrated plans to improve drainage. De Crosne's reason for his decision was his fear that without these communal rights, a number of families in each community would be unable to "pay their taxes." See Archives nationales, Q1 1381 (Nov. 28, 1780).

Since communal land was often marginal, one might ask whether preserving communal rights really did depress agricultural productivity seriously. Contemporaries thought so, and it is worth noting that certain communal rights, in particular vaine pâture, reduced every property owner's incentive to adopt new agricultural technologies. Banning sales of such communal rights to private individuals, as the French state did, blocked one simple way to restore the proper incentives (a "Coase theorem" resolution of the externalities), and it saddled most new technologies with insurmountable free-rider problems. The result was fewer enclosures and fewer agricultural improvements in general. This topic will be explored more fully in a book I am preparing on the social and economic history of the French countryside. 
These were not the only costs of the tax system. The taxes drew money away from peasants and farmers, and thereby reduced agricultural development. Why fence a plot of land or drain a fen when the tax collector would simply use the improvement as a reason to boost the taille? As Vauban complained in 1707,

things are reduced to such a state . . that a man who could use his own talent and skill in order to ameliorate his life and that of his family prefers to stay as he is without doing anything. A man who could raise several cows or lambs, which could improve his farm or his land, is obliged to do without them, lest he be crushed by the taille the following year, as he most certainly would be if he earned a little something and it was seen that his harvest was a bit more abundant than usual.

To be sure, French taxes on average may not have borne down so heavily as some historians once imagined: if the central government's figures can be believed, per capita taxes were in fact higher in England than in France by the eighteenth century. But French taxes did penalize investment, particularly by peasants who lacked exemptions. The net effect retarded agriculture. ${ }^{34}$

Equally hurtful were the resources wasted avoiding or manipulating taxes. Some peasants in Normandy, for instance, paid for fictional second residences in cities in order to claim urban tax exemptions; others refrained from erecting new buildings that might increase their assessment. Time and effort were spent on reducing tax assessments, influencing the local élu or bribing the village collector. The tax collectors themselves spent resources in the search for bribes. Contemporaries complained that even village tax collectors devoted "all of their energy, for days and nights without interruption, to the task of seeking out bribes." The result, as one historian has noted, was a "perversion" of entrepreneurial talent, a perversion visible even at the village level. The tax system diverted resources into the task of "redistributing the

\footnotetext{
${ }^{34}$ Vauban, Projet, p. 28. Mathias and O'Brien show that by the eighteenth century the central government's tax receipts were lower per capita in France than in England, but the central government's figures may understate the size of French fiscal levies. In any case, Mathias and O'Brien acknowledge that French taxes did seriously penalize investment. This was particularly true in agriculture. The French peasant, for example, payed a higher taille if he improved his land; by contrast, the eighteenth-century British landowner owed what was in effect a fixed (and in real terms declining) land tax assessment that, as Adam Smith noted, "did not discourage .. improvements, nor keep down the produce of the land below what it would otherwise rise to." Similarly, although the excise on beer in England may have reduced the demand for barley a bit, it was also part of a system of protection that guarded British farmers against foreign competition. The key here, of course, is not per capita taxation, but the incidence of taxes and their effect at the margin, and as Adam Smith noted, French taxes, though apparently lower by the eighteenth century on a per capita basis, were far more oppressive. See Mathias and O'Brien, "Taxation," pp. 614-17, 621-25; Adam Smith, An Inquiry into the Nature and Causes of the Wealth of Nations, ed. Edwin Cannan, 2 vols. in 1 (Chicago, 1976), vol. 2, pp. 352-58, 365, 437-38; C. D. Chandaman, The English Public Revenue, 1660-1688 (Oxford, 1975), pp. 9-76, 188-91; W. R. Ward, The English Land Tax in the Eighteenth Century (Oxford, 1953), pp. 3-7, 20-22, 34-35, 67, 87-88, 93-97.
} 
nation's wealth rather than into increasing wealth." ${ }^{35}$ It was not a costless transfer from the peasantry to the rest of society.

Did the fiscal system work nothing but harm in the countryside? It may have helped create larger, more efficient farms, the sort of farms common in England but rare in France. The failure of French agriculture is traditionally blamed on the lack of such farms, and the exemptions may have offset some of the harm done by the rest of the tax system. But the privileged might well have exploited their managerial skills to assemble large, well-run farms without the impetus of tax exemptions. Furthermore, when privileged landlords attempted to enclose their fields or to undertake other improvements associated with English agriculture they faced the obstacle of a government that protected communal property rights to preserve its taxes. And the fiscal system in any case blocked improvements by the largest single group in rural society, the peasants themselves.

${ }^{35}$ Esmonin, La taille, pp. 270-71, 354; Wolfe, Fiscal System, p. 249. See also Vauban, Projet, pp. 27-28, 35-38. 